\title{
A KÖZIGAZGATÁSI TÉRFELOSZTÁS VÁLTOZÁSAI MAGYARORSZÁGON
}

\author{
(Changes in the Administrative Spatial Division of Hungary) \\ HAJDÚ ZOLTÁN
}

\section{Bevezetés}

A gazdasági, társadalmi, politikai környezet mindenkor meghatározta a közigazgatás hierarchikus tagolását, funkcionális és terủleti rendjét, valamint szervezeti struktúráját. Magyarországon a települési (kőzségi, városi) és a területi (járási, megyei, regionális) igazgatás egyaránt mély történeti fejlődési sajátosságokkal rendelkezik.

A magyar közigazgatás fejlődésének egyik meghatározó sajátossága, hogy a helyiterületi igazgatást tekintve a helyi igazgatás évszázadokon keresztül gyenge volt leszámítva a szabad királyi, majd törvényhatósági jogú városokat. A megye és a megyerendszer a magyar történeti, társadalmi, politikai, továbbá közigazgatási tértörténeti fejlődés egyik meghatározó eleme, a járási és a regionális felosztás inkább esetleges jellegü. Hosszú évszázadokon keresztủl a megye volt a társadalmi, politikai közélet színtere, valamint a közigazgatás és az igazságszolgáltatás legfontosabb szintje, kerete. A változás és a stabilitås egyaránt jelen van a megyerendszerben, a megye alkalmazkodóképessége rendkívül jelentőssé vált. Korszakonként eltérö jelleggel fogalmazták meg a megyék feladatait (mindig mást jelentett megyének lenni), illetve a megyék sajátosan újraélték helyưket, szerepüket, a "mindenkori közigazgatási középszint" kőzjogi, igazgatási és politikai tartalmát.

Tértörténeti szempontból az adta a megyerendszer jelentőségét - bár története során csak rövid ideig volt kizárólagos és egyetemleges területi képződmény -, hogy térbelileg minden vagy a megyébe vagy a megyére épült rá, így az a történeti-területi folyamatok meghatározó kerete volt hosszú századokon keresztủl.

A járási felosztás és annak változtatása évszázadokon keresztül megyei hatáskörbe tartozott. A járási egységek szerepe csak rövid időszakokban értékelődött fel. A járás - a megyével szemben - nem vált területi identitást meghatározó térkategóriává.

A megyék feletti regionális igazgatás a magyar kőzigazgatás- és tértörténet legproblémásabb része. A szakigazgatásban viszonylag korán létjogosultságot kapott, az általános igazgatásban csak ideiglenes jelleggel, elsősorban diktatórikus törekvések időszakában érvényesült.

A közigazgatási tér lényegi változásait tértörténeti szempontból vizsgáljuk (s terjedelmi korlátok miatt csak részben dokumentáljuk ábrákkal ezeket), e mellett csak érintőlegesen utalunk az őket meghatározó általános folyamatokra. 


\section{A közigazgatási térfelosztás történeti változásai}

A magyar közigazgatás fejlődése sokféle szempontból szakaszolható, s a magyar igazgatástörténeti irodalom többféle alperiodizálást dolgozott ki (Ereky 1. 1910, Beér J.Csizmadia A. 1966, Csizmadia A. 1976, Szamel K. 1981). A gazdasági-társadalmi formációk váltásokhoz (feudalizmus, kapitalizmus, szocializmus) kötött szemlélete alapjản a strukturális változások meghatározó jegyei jól megfogalmazhatók, s ugyanakkor az egyes formációk belső fejlődése is szakaszolható. A társadalmi-gazdasági-politikai váltások a legszélesebb síkon határozták meg a közigazgatás és térbelisége környezetét.

$\mathrm{Az}$ államtörténethez és az állam területi struktúrájához, határainak változásához kötöłt szakaszolások: a független magyar feudális állam (1526-ig), a területileg megosztoł államfejlődés szakasza (1526-1686), a Habsburg uralmi térbe rendezett államfejlődés (1918-ig), s a szuverén magyar államfejlödés időszaka (1918-tól) szerint az állam strukturális átalakulásai a belső közigazgatási tér változásaira is meghatározó jelentőséggel bírtak (Edelényi-Szabó D. 1928, Ember Gy. 1946, Eszláry K. 1947, Némethy A. 1958). Az államterủlet mindenkori alakulása "keretjelleggel" határozta meg a belső közigazgatási területfelosztás lehetóségeit.

A különböző szempontú megközelítések és korszakhatárok nem igazodnak mechanikusan egymáshoz. Ha pl. a megyére vetítjük ki az elöbbieket, akkor a történeti folyamatok lényegét és váltásait visszatükrözi a királyi, nemesi, modern polgári, tanács-, továbbá az új önkormányzati megyére való tagolás. A felsorolás már önmagában is jelzi, hogy a megye rendkívül sajátos, a magyar állam "életrajzát" szinte teljes mértékben végigkísérő valami; funkció- és rendszerspecifikus jelleget egyaránt visel, rendkívül sajátos alkalmazkodóképességgel rendelkezik.

\section{1) A feudális közigazgatás térbelisége 1848-ig}

A magyar államalapítás és államszervezés tudatos politikai döntéseken alapult. Géza fejedelem és Szent István uralkodása alatt a különböző jellegü területi struktúrák (törzsi, nemzetségi, "modern állami") együttéléséröl beszélhetünk. Az állam- és egyházszervezés párhuzamos folyamatként játszódott le. Az egyházszervezésben általános európai meghatározottságok érvényesültek.

\section{a) A királyi vármegye}

A királyi vármegyék eredetének (szláv, frank-bajor, egyházi, ázsiai nomád, belsó fejlỏdésủ magyar stb.) megítélése mind a mai napig éles történeti viták tárgya. Valószínủleg azoknak van igaza, akik úgy vélik, hogy a Szent István-kori megyével és megyerendszerrel kapcsolatos forrásismereteink nem teszik lehetővé sem a megyék eredetének, sem pedig kialakulásának, szerepének, belsó struktúrájának, számának és határainak pontos megállapítását (Kristó Gy. 1988), s valójában különböző indíttatású hipotézisek állnak szemben egymással a legtöbb tekintetben.

A királyi vármegye jellegében magában hordozta a királyi magángazdasági-igazgatási funkciókat. Vélhetően megjelentek benne valamilyen módon a közhatalom elemei is; a XI. századtól kezdve fokozatosan kőzigazgatási, védelmi és igazságszolgáltatási szerepet kapott a megye, s vezetője, az ispán. (Valószínüleg a magángazdasági és közhatalmi 
elemek sajátos keveredése miatt nem szóltak Szent István törvényei részletesen a vármegyékröl. Nehéz ugyanis feltételezni, ha a vármegyék egyértelmüen és kizárólagosan a tudatos, szisztematikus államszervezés alapelemei lettek volna, akkor ne szabályozták volna müködésüket, szervezetüket.)

A megyék számát és területi konfigurációját nem lehet pontosan megállapítani, de ennek ellenére nagyon sok történeti-területi rekonstrukciós próbálkozás született a Szent Istvánkori megyékre vonatkozóan (Györffy Gy. 1963, 1977, Holub J. 1938, Hóman B. 1935, Kristó Gy. 1988). A történeti hagyomány 38-45-re teszi a Szent István által alapitott megyék számát, de az újabb kutatások csak 25-30-at tudnak azonosítani, bizonytalan területi kiterjedés mellett. Nagy valószínüséggel a megyék nem alkottak egybefüggö területet (különösen nem az ország egészére kiterjedöen), a területi elhatárolódás a más je!legủ terúleti struktúrákkal kapcsolatban volt fontos. A királyi vármegye mellett már a korai feudalizmus id cuikában megjelent egy másik képződmény, a határvármegye is. Ezek a határvármegyék az orszáa külsö határainak védelmére szerveződtek, elsősorban székely lakossággal.

A XII. századtól a források nagyobb mélységben tárják elénk a királyi vármegyét, $\mathrm{s}$ ezek függvényében nyomon követhető az a folyamat, melynek során a vármegye patrimoniális hirályi magánbirtokból elsődlegesen közjogi intézménnyé válik, szerepe ettől kezdve felértékelödik. Stabilizálódik a megyék száma (1158-ban 70, 1184-ben 72 megyéröl tôrténik említés), s valószínüleg megszilárdulnak a megyehatárok is.

A külföldi betelepítésekkel homogén nemzetiségi területek jöttek létre (szepesi, erdélyi szászok), melyek fokozatosan területi jellegü, megyétől elkülönülö, külön jogállású területekké szerveződtek. A székely székek, a megyék és a szász székek egymás mellett ellése Erdély belső igazgatását, a vajda pedig az általános igazgatásban regionális jelleggel képviselt egyfajta sajátosságot.

\section{b) A nemesi megye évszázadai (Járási és regionális elemek a területfelosztásban)}

A királyi vármegyét "felváltó" nemesi megye története során maga is többször változott; âtalakult államszervezeti helye, súlya, szerepe; közigazgatásban betöltơtt funkciója folyamatosan erösödött; s az államhatárok mozgása következtében változott a megyék száma, határa és belsỏ területi tagolása.

A feudális társadalom államszervezeti viszonyait is érintö 1222-es Aranybulla már megjelenítette a nemesség súlyát, majd a megyénként szervezödớ nemesség kialakitotta a maga területi önkormányzatát, sajátos szervezetét, társadalmát és hatalmát. Az 1232-es kehidai oklevél azt jelezte, hogy a nemesség önvédelmi és igazságszolgáltatási szerepet kivánt a megye s a maga számára. A megyei autonómia elsősorban a törvénykezéssel, az igazságszolgáltatással indult fejlödésnek. Jelentős nagyságbeli különbségek voltak az egyes megyék között, és eltéröen alakult az egyes országrészek "megyesürüsége": a BudaPozsony közötti szakasz elaprózódott, az Alföld nagy része viszont nagy kiterjedésü megyehálózattal bírt.

A kunok és a jászok befogadásával az ország belső magterületén etnikumhoz kötött kiváltságos területek jöttek létre. A kiváltságos terület lakossága és a megyei nemesség együittélése az eltérő gazdasági, társadalmi fejlettség miatt összeütközésekkel terhelt volt.

A megyén belüli területi szervezödésben új elemként jelentkeztek a járások. A járási felosztás (általában minden megye 4 járásra tagolódott) a XIII. század végétöl jelent meg, és elsősorban a megyei igazságszolgáltatásban kapott szerepet. 
A regionális jellegủ felosztás és kỏzigazgatás egyrészt a különbözỏ közjogi jelleggel bíró országrészekhez kapcsolódott, másrészt szakigazgatási jelleggel a pénzügyigazgatás területén állandósult.

A XV. század végére vonatkozóan Ernuszt Zsigmond kincstartó 1494-1495. évi számadásaiból, valamint Csánky Dezső életművéböl alkothatunk képet a megyék gazdasági, népességi, települési viszonyairól, s területi rendjéröl. A Mohács elốtti, "szervesen fejlödött", független Magyarország területi struktúrája és közigazgatási beosztása magán viselte az állam addigi fejlödésének minden jegyét. A regionális közigazgatás fejlődésének elemei jelentek meg Erdély, Szlavónia és Horvátország, valamint a bánságok esetében ( 1 . ábra).

A mohácsi csatavesztés, majd az ország három részre szakadása alapvetően új történeti helyzetet teremtett. Ennek a korszaknak meghatározó eleme az ország területi szétdarabolása, "különutas" fejlődése. Az ország közepén a török saját érdekei és stratégiai térszemlélete alapján rendezkedett be, felszámolta a megyerendszert. A királyi Magyarország folyton változó területi keretek között, a megyei rendszer szempontjából viszonylagos jogfolytonosságot biztositott. Az önálló Erdélyi Fejedelemség a magyar nemzeti hagyományok folytatója volt - minden belsỏ sajátossága ellenére.

Az alföldi nemesség a török megszállás ellenére sem adta fel megyei tudatát, kötődését, részben szervezettségét. $\mathrm{Az}$ elmenekült nemesek fenntartották a megyei szervezetet. Önállóan, vagy valamely más megyével egyesülve tartották gyüléseiket (Pest Csongráddal, majd Heves Csongráddal, Somogy Zalával stb.), illetve a törvényhozás ideiglenesen egyesítette a megszállt területek megyei közgyüléseit (1569. évi 52. tc. Heves-KülsőSzolnok). Ez világosan mutatja, hogy a nemesi megyének nem a területisége volt az elsödleges lényege, hanem a nemesi, személyhez kötött jogok és kiváltságok gyakorlása.

Az államterület megosztottsága a török hódoltság és Erdély határán a Partium révén új területi fogalmat szült. A "Részek" feletti uralom többször változott.

Bocskay István saját birtokán a hajdúk 1606-os letelepítésével, kollektív nemesi jogok adományozásával új társadalmi csoportot és téregységet alapozott meg. A hajdúk és Szabolcs megye küzdelméböl végül is a hajdúk kerültek ki győztesen, az 1791. évi országgyủlés külön törvényhatóságként ismerte el a Hajdúkerületet.

Az 1686-os háború révén az ország nagy része felszabadult a török hódoltság alól, s azonnal felvetödött kérdésként a közigazgatási területi struktúra alakításának mikéntje is. A magyar nemesség elsősorban a korábbi állapotok visszaállításában volt érdekelt, de ezeket a törekvéseket megakadályozta részben a korábbi közigazgatási viszonyok pontos ismeretének a hiánya, föként pedig a bécsi udvar törekvése. A bécsi udvar a katonai határőrvidék felállitásával jelentős területeket vont ki a megyerendszerbỏl (a katonai határörvidék olyan funkcionális védelmi tér volt, mely regionális jellegünek tekinthető egészében, az ezredek területe képezte a megyei szintü, a századoké a járási szintủ területi egységeket, s maga is sokat változott a XIX. század utolsó harmadáig, teljes megszüntetéséig), s különösen az Alföldön a saját érdekeit érvényesítette a megyék újraszervezése során.

Mária Terézia erőteljesen kiszélesítette a közigazgatás feladatait, s 1768-as föispáni utasitása elöször foglalta keretbe a vármegyei igazgatás egészét. A megyék fokozatosan az osztrák központositó törekvésekkel szembeni ellenállás, a magyar nemzeti gondolat és törekvések letéteményeseivé váltak. 


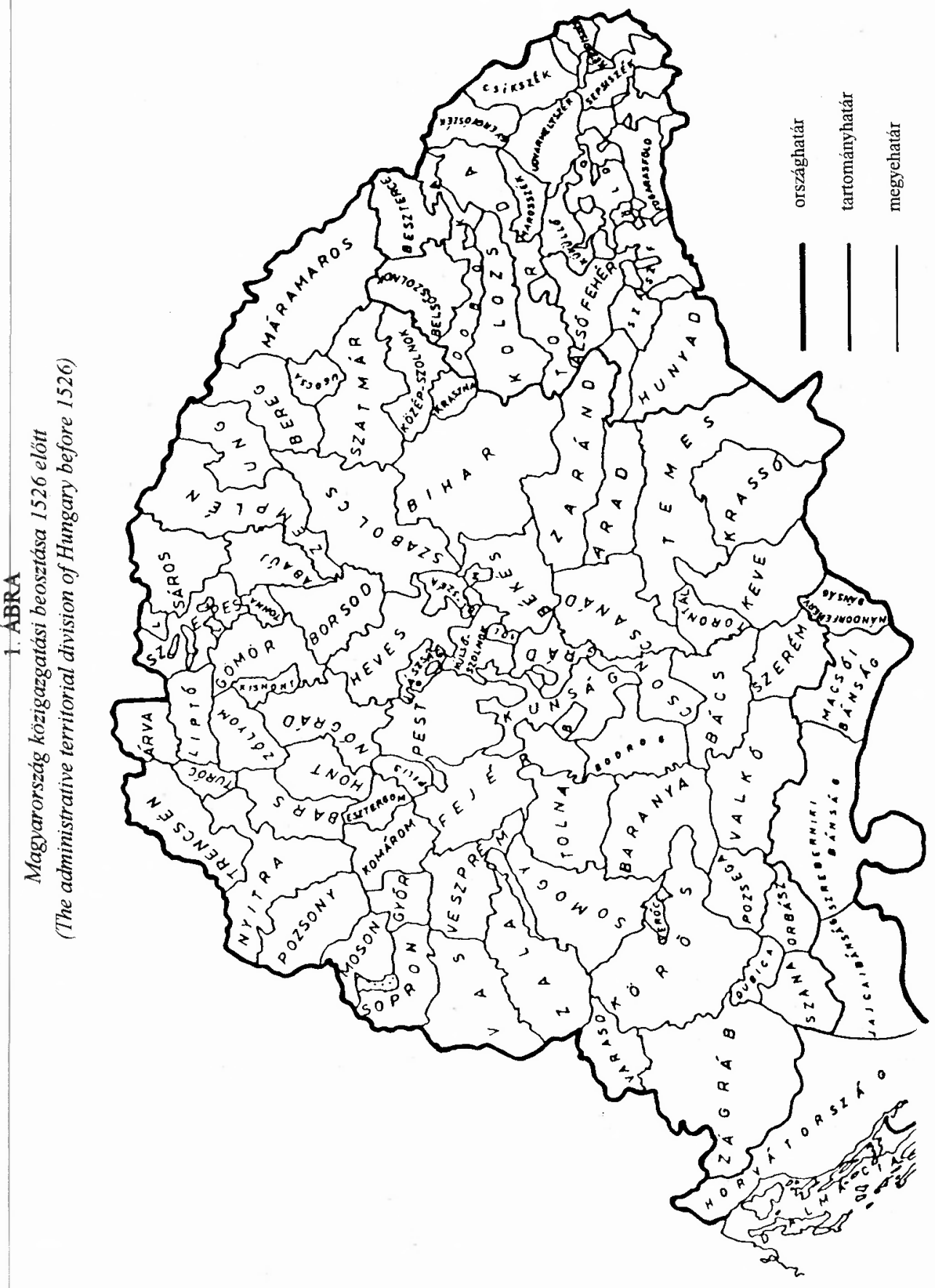


Különösen élesen jelentkezett ez a probléma II. József tevékenysége kapcsán. II. József a felvilágosult abszolutizmus jegyében, az általa elképzelt, felülröl vezérelt modernizáció érdekében megszüntette a nemesi vármegyék autonómiáját. Magyarországot 10, Erdélyt pedig 3 kerületre osztotta fel (racionalizálta a megyei területbeosztást is, egyesítette Mosont Györrel, Komáromot Esztergommal, Abaújt Tornával, Bereget Ugocsával, Békést, Csanádot és Csongrádot). II. József reformja során a közigazgatás teljes területi hierarchiája (járás, megye, régió) megváltozott, s új módon épült ki.

A korszak koncentráltan vetette fel az ország teljes problematikáját, benne a közigazgatás helyzetét: "idegen központi hatalom" - nemzeti megyei hatalom; modernizáció - történeti hagyományok; állam - társadalom viszonya; nemzet - ország; soknemzetiségủ birodalom - monopolisztikus nyelvi törekvések; soknemzetiségủ Magyarország - magyar államnyelv követelése; modern állami közigazgatás, racionális közigazgatási területszervezés - történeti megyerendszer; önkormányzati - állami közigazgatás stb. Az egész reformkor tulajdonképpen nem egyéb, mint a II. József időszakában felvetődő kérdésekre való nemzeti válaszkeresés és megoldási törekvések idöszaka. A XIX. század elsö felének államfilozófiai, állam- és társadalomszervezési vitái, nálunk a centristák és a municipalisták közel évszázados küzdelmében csúcsosodtak ki. Mindkét oldalon a szellem és a közjog óriásai, a nemzeti elkötelezettség élharcosai vettek részt a vitában, de alapvetö, ellentétes értékítéleteiket, politikai államépítési, hatalmi céljaikat nem tudták, talán nem is akarták összehangolni (Eötvös J. 1902).

A XIX. század közepén a nemesi vármegyék a területi közigazgatás alapvetỏ egységei, az általános közigazgatás hatóságai. A legfontosabb vezetö elit a jómódú középbirtokos nemesség volt, míg a kisebb tisztségekbe kisnemesek is bekerülhettek. A XIX. század elsỏ felére a legnagyobb nemesi lakossággal rendelkezö megyékben 5-7 ezer fö között mozgott a közgyüléseken potenciálisan megjelenhetők létszáma. A nemesi megye közgyülése választotta a megye képviselöit az alsótáblába, látta el utasítással, döntött esetleges visszahívásukról. A megyei közgyülés így államépítő és törvényhozó befolyással is rendelkezett. Részben a megyei közgyúléseken nött politikus óriássá a XIX. század első felének reformnemzedéke. A nemesi vármegye rendkívül sajátos képződmény volt. $A$ megyei nemesség önkormányzataként befelé alapvetően demokratikus (érvényesítette a magyar szokásjog alapintézményét, nevezetesen, hogy minden nemest egységesen megilletỏ jogok vannak), sőt, egyes korabeli alkotmányjogászok szerint szinte köztársasági jellegü, önálló egyéniség volt, "a magyar lélek és jog csodálatos alkotása". "Kifelé" és "lefelé" kevésbé demokratikus jelleget mutatott. Az önkormányzat rendkivül magas szintü volt, a megyei nemesség ügyeit a maga választotta tisztségviselók intézték, a megyei gyülést még az uralkodónak sem volt joga felfüggeszteni. A megye a részére végrehajtás céljából megküldött rendeleteket a tơrvényesség szempontjából megvizsgálta, s a törvénytelennek minősítetteket nem hajtotta végre ("passzív resistentia").

A megye az állam minden tevékenységének, megnyilvánulásának (törvényhozás, közigazgatás, igazságszolgáltatás stb.) részese, területi szinten megvalósítója, képviselője volt. A nemesi érdekek rendíthetetlen védöbástyája rendkívull sok hivével, s a korabeli politikai irodalmat tekintve szinte ugyanannyi rendkívül kemény ellenféllel bírt. $A$ megye olyan kulcspozíciót foglalt el, hogy csak egyet nem lehetett tenni: figyelmen kivül hagyni.

A feudalizmus utolsó időszakának területi felosztása rendkívül tarka és térbelileg aránytalan struktúrát mutatott. Belső szerkezetében is erőteljesen eltéró jellegü egységekként mủködtek (Fényes E. 1847). A középszintủ általános közigazgatási egységekre eltérỏ számú és területi konfigurációjú regionális szakigazgatási beosztás épuilt. 


\section{2) A modern polgári közigazgatás térbeli összefüggései}

\section{a) $A$ "legitim" polgári kốzigazgatás}

$\mathrm{Az}$ 1848. márciusi-áprilisi tơrvények szinte minden tekintetben megrendítették a régi nemesi vármegye alapjait. A népképviseleti alapon létrejövő Országgyüléssel megszünt a megyék régi, alapvetően fontos joga, az országgyűlési követküldés, felhatalmazás és visszahívás. A megye megszünt a törvényhozás részese lenni. A felelős kormány felállítása, a központi közigazgatás szerveinek "magyar kézre kerülése" feleslegessé tette a megye korábbi politikai, nemzet- és alkotmányvédő szerepét, söt a kormány munkáját veszélyeztette volna a megyék korábbi politikai szerepének, jelentőségének a megmaradása.

A forradalom és szabadságharc időszakában csak a megyék funkcionális reformjára került sor, a radikális területi reformok lehetőségeit - köztük Táncsics Mihály megyerendezési tervét is - elutasították.

\section{b) Az "illegitim" polgári közigazgatás}

A forradalom és szabadságharc leverése után berendezkedő osztrák önkényuralom egyaránt lesújtott a központi és a megyei közigazgatás képviselőire, szervezeteire. Először ideiglenes, majd 1854-ben "végleges" területi reformot hajtottak végre. A történeti Magyarországot 5 nagy részre (Magyarország, Szerb Vajdaság és Temesi Bánság, Erdély, Horvát-Szlavonország, Katonai határörvidék) darabolták (Fényes E. 1857). Magyarországot 5 kormánykerületre (soproni, pozsonyi, kassai, nagyváradi, pest-budai) osztották, megye- és járási reformot hajtottak végre, szabályozták a községi igazgatást.

\section{c) A kiegyezés utáni polgári közigazgatás térbelisége}

A kiegyezés után szinte az államstruktúra rendezésével párhuzamosan a bíráskodást elválasztották a közigazgatástól, s rendezték a törvényhatóságok helyzetét, jogállását, feladatait és intézményrendszerét. A köztörvényhatóságokról szóló 1870. évi 42. tc. szerint a törvényhatóság gyakorolja önkormányzat jogait, közvetíti az állami közigazgatást, s élhet politikai jogaival, ami ez esetben azt jelenti, hogy a törvényhatóság közérdekü, sőt országos ügyekkel is foglalkozhat, azokban állást foglalhat, állásfoglalását közölheti a többi törvényhatósággal, a kormánnyal és a képviselöházzal.

A törvényhatóságok területrendezésére az 1876. évi 33. tc.-ben került sor. $A$ rendezés egyik legfontosabb összetevóje, hogy megszüntette a feudális eredetũ területi önkormányzatokat, az ország történetében elõször - a katonai határörvidék maradványainak kivételével - egyetemlegessé tette a megyebeosztást.

A területrendezés Erdélyben és a Felvidéken kiterjedt területeket érintett. A mai Magyarország területére vonatkozóan a legfontosabb rendelkezése Hajdú és JászNagykun-Szolnok megye létrehozása, Pest-Pilis-Solt megye Kiskunsággal történő kiegészítése volt. Más esetekben csak az enclavék és exclavék megszüntetésére szorítkozott.

A magyar kőzigazgatás a dualizmus időszakában különleges jelleggel alkalmazta a községek városi igazgatás alá rendelését. Ilyen konstrukció jött létre Fiume és 3 község között az egész korszakra vonatkozóan, időszakos jelleggel pedig 7 kőzség és Körmöcbánya rendezett tanácsú város között. 
Az 1876-os területi rendezés után 1918-ig megyei szinten csak kisebb korrekcióra került sor. Végbement a határörvidék polgárosítása, 1880-ban Szörény megyét egyesítették Krassóval, Tornát 1881-ben Abaúijal. 1886-ra befejeződtek a kisebb területi korrekciók is (1. táblázat).

\section{3) A közigazgatási struktủra és a területi reform a Tanácsköztársaság térszervezésében}

Az Osztrák-Magyar Monarchia vesztesen került ki az I. világháborúból, s a katonai vereség, a győztes nagyhatalmak háború elötti és közbeni ígéretei, szerződései, a belsó érdekellentétek, a nemzeti törekvések megpecsételték a Monarchia sorsát. Egy rendkívül bonyolult, ma nosztalgiával tekintett közép-európai nagyhatalom tünt el vele a térképröl.

A Magyar Népköztársaság, majd a Magyarországi Tanácsköztársaság is szembekerült a politikai struktúra és a közigazgatási tér újjászervezésének feladataival. Az ideiglenes alkotmány hierarchikus alapon rendezte a települési, a járási és a megyei tanácsok viszonyait. A járás először vált integráló általános közigazgatási szintté.

A területrendezés átfogó reformjára nem került sor, de Zala megye Észak- és Dél-Zalára való osztása csaknem fegyveres konfliktussá fajult a két megyei direktórium között. A konfliktus jelezte, hogy a történeti struktúrák és a városok közötti ellentétek, szembenállások nem rendezhetőek gond nélkül ideológiai alapon sem.

\section{TÁBLÁZAT}

A megyei és járási szintũ közigazgatás felosztás alakulása a mindenkori magyar állam területén (1857-1984)

(The development of the county and district level administrative division in the territory of Hungary) (1857-1984)

\begin{tabular}{|l|c|c|}
\hline Év & $\begin{array}{c}\text { A megyei szintú közigazgatási egységek } \\
\text { (megye, szék, ezred, vidék stb.) }\end{array}$ & $\begin{array}{c}\text { A járási szintú közigazgatási egységek } \\
\text { (járäs, század, városkörnyék stb.) } \\
\text { száma }\end{array}$ \\
\hline 1857 & 78 & 613 \\
\hline 1870 & 102 & 666 \\
\hline 1873 & 97 & 672 \\
\hline 1897 & 72 & 483 \\
\hline 1900 & 72 & 484 \\
\hline 1918 & 72 & 512 \\
\hline 1922 & 34 & 161 \\
\hline 1923 & 25 & 161 \\
\hline 1937 & 25 & 149 \\
\hline 1938 & 31 & 172 \\
\hline 1939 & 34 & 184 \\
\hline 1940 & 44 & 246 \\
\hline 1941 & 44 & 264 \\
\hline 1945 & 25 & 151 \\
\hline 1949 & 25 & 150 \\
\hline 1950 & 19 & 140 \\
\hline 1960 & 19 & 128 \\
\hline 1970 & 19 & 107 \\
\hline 1980 & 19 & 132 \\
\hline 1984 & 19 & 139 \\
\hline
\end{tabular}




\section{4) Az államhatárváltozások (1920-1944) közigazgatási következményei}

Az 1920-as trianoni békeszerződés kővetkeztében alapvetően átrendeződött az ország térszerkezete, megváltozott a közigazgatási területbeosztás rendszere, kiéleződtek a korábban is meglévő aránytalanságai (2. ábra). Az ország visszanyerte teljes szuverenitását, de a magyar társadalom nem igazán tudta ezt értékelni a területi és a népességi veszteségek miatt.

Az 1923. évi 35. tc. II. fejezete rögzítette a megyei közigazgatás új területi rendjét. Az ideiglenesség és a területi revíziós igények fenntartása jegyében csak az új államhatár által kettévágott csonka megyéket egyesítették (Mosont, Pozsonyt Győrrel, Esztergomot Komárommal, Hontot Nógráddal, Gömör-Kishontot Borsoddal, a 2 községböl álló Ungot Szabolccsal, Bereget Szatmárral, Aradot, Csanádot Torontállal). A megyék száma így 341öl 25-re csökkent.

A II. világháború előtt és alatt sor került az államhatárok változására, s a négyszeri területgyarapodás következtében folyton változott a közigazgatási beosztás is. Új allamszervezeti problémaként kezelték Kárpátaljăt, mint az új államhatárokon belül a legnagyobb összefüggő nemzetiségek által lakott területet, $s$ sokféle terv készült a Kárpátaljai Kormányzóság alkotmányos különállásának meghatározására.

\section{5) A koalíciós közigazgatás (1945-1948) térszervezési dilemmái}

Az 1944 decemberében, az ország területén folyó háború idöszakában megalakult Ideiglenes Nemzeti Kormány első debreceni intézkedései közé tartozott a közigazgatás ideiglenes rendezése. Az államszervezet helyreállítása és az önkormányzatok újjáalakítása erdekében elrendelték, hogy az önkormányzatok önállóan, a maguk erejéből gondoskodjanak az igazgatási szervek létrehozásáról, müködésük biztosításáról, mégpedig azoknak az elveknek megfelelöen, amelyeket az Ideiglenes Nemzetgyülés és az Ideiglenes Nemzeti Kormány elfogadott és kinyilvánított.

A 14/1945. M. E. rendelet a közigazgatási önkormányzati alapokról, mégpedig a korábbi területi és szervezeti struktúrának megfelelő helyreállításáról illetve megújításáról intézkedett. E rendelkezés a jog-, teruleti és szervezeti folytonosság alapján állt, a \$zuikséges módositások lehetőségének elismerése mellett.

A fegyverszüneti egyezménynek megfelelóen az Ideiglenes Nemzeti Kormány hatályon kívül helyezte az országhatár-változásokat becikkelyezỏ törvényeket illetve rendeleteket. A 4330/1945. M. E. rendelet az újonnan tudomásul vett államhatárokhoz igazította az ország közigazgatási beosztását. Egyesítette Komárom és Esztergom, Nógrád és Hont, Borsod, Gömör és Kishont, Szatmár, Bereg és Ugocsa megyék Magyarország határai között maradt részeit. A földrajzi tényezők és a közlekedési nehézségek figyelembevételével a törvényhatóságok között is területátcsatolásokat rendelt el, melyek elsősorban egyes községek korábbi teruletátcsatolási kérelmére hivatkoztak. Sor került néhány járás (a tornai járás Abaújból Borsod-Gömör-Kishont megyébe, a balatonfüredi járás nagy része Zalából Veszprémbe) átcsatolására is. A 29 pontban tételesen felsorolt atcsatolásokat 1945. december 31-ig kellett volna végrehajtani, de amint az 1947-es Helységnévtárból meggyőzódhetünk róla, nem került sor teljes körü végrehajtására. 


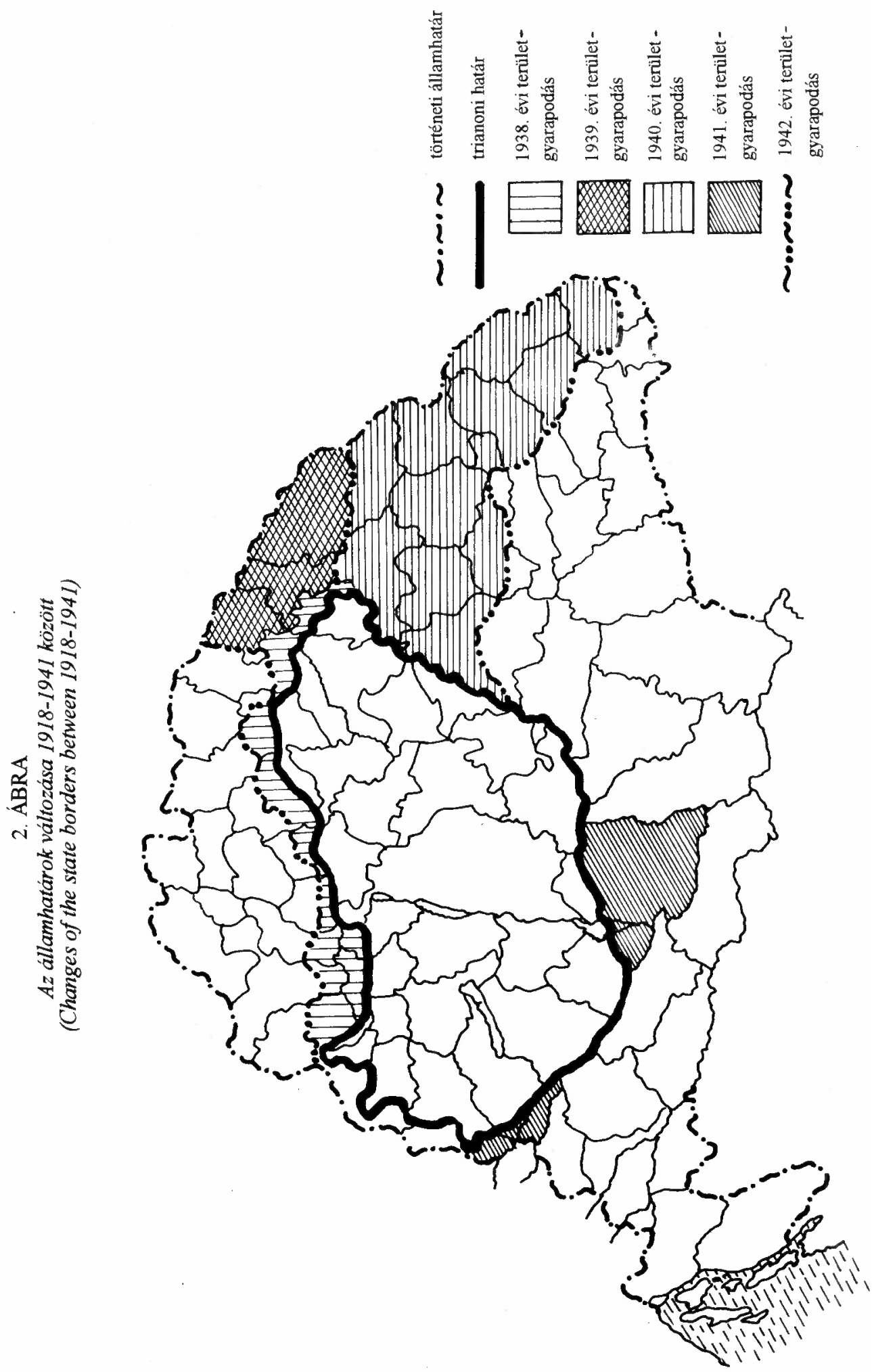


A koalíciós időszak közigazgatási reformelképzelései az egyes pártok gazdasági, társadalmi, politikai céljaihoz és hatalmi törekvéseihez igazodtak elsősorban. Minden párt jövőképének megfelelöen tervezte a közigazgatás struktúráját, müködési rendjét, területi beosztását, de az érdekellentétek miatt - a nagyszámú terv ellenére - nem került sor radikális közigazgatási reformra.

\section{6) Az államszocializmus 40 éve}

A tanácsrendszer bevezetését végül is a külsỏ meghatározottságok, valamint az MDP belső, voluntarisztikus gazdaság- és társadalomátalakítási céljai tették szükségessé a hatalom új birtokosai şrámára. Az 1949-es alkotmány már alapjaiban meghatározta az allam új struktúráját, benne a közigazgatás, s azon belül a megyék új helyzetét és szerepét. Az I. tanácstörvényre tulajdonkeppen már csak a részletek megfogalmazása maradt (Horváth M. T. 1989).

Az új struktúra legfontosabb összetevője, hogy tudatosan felszámolta az önkormányzati jellegü igazgatást, totálisan államositotta a közigazgatást. A törvény az allamszervezetben helyezte el a tanácsokat, megfogalmazta pártirányitásukat, meghatározta hierarchikus struktúrájukat, világosan kimondta alá-fơlé rendeltségük jellegét. Az államhatalmi jelleg mellett a törvénybe bekerült ugyan a tanácsok tömegszervezetként való meghatározása is, de ez érdemi tartalmat nem kapott.

$\mathrm{Az}$ állami és közigazgatási struktúra reformja után került sor a területbeosztás atalakítására. Megyei szinten az átalakitás tudatosan mérsékelt jelentöségủ volt, hiszen kimondták, hogy csak a legszükségesebb esetekben kell a megyék határaihoz "hozzányúlni", a korábbi struktúrát az új hatalom érdekében kell felhasználni (Hajdú Z. 1991). A meghatározott célnak megfelelően az átszervezés eredményeként a megyék száma 25-rỏl 19-re, a járásoké pedig 150-röl 140-re, a községeké 3250-röl 3169-re csökkent, s létrehozták Nagy-Budapestet (3. ábra).

A tanácsrendszer bevezetésekor a területi szintek (megye, járás) felértékelödtek, hiszen Budapest kivételével a városokat a megyei és a járási tanácsok alá rendelték. 24 város a megyei, 29 pedig a járási tanácsok igazgatása alá került. A megyebeosztás radikális reformjára 1953-ban és 1956-ban tervek szullettek, de végül is nem került sor alapvetö reformra. Az államszocializmus időszakában a megyei beosztás relatíve felértékelödött. Lényegesebb területi változást csak a keszthelyi járás Zala megyéhez tơrtént visszacsatolása jelentett 1979-ben. Az 1954-es II. tanácstörvény módosította a területivárosi igazgatás viszonyait. A nagyvárosokat (Debrecen, Miskolc, Pécs, Szeged) kivette a megyei tanácsok igazgatása alól, és megyei jogú várossá alakította át öket, a többi város pedig járási jogú várossá alakult át.

1969-ben kísérleti jelleggel Hatvan (3 község) és Kapuvár (4 község) körül létrejött a "városi igazgatású község" konstrukció, melyben a városi tanácsok átvették a járási tanácsok községekkel kapcsolatos jogosultságait.

Az 1971-es tanácstörvény újrafogalmazta a tanácsok szerepét, s azokat a "... nép hatalmát megvalósító șzocialista államnak, a demokratikus centralizmus alapján múködő népképviseleti-önkormányzati és államigazgatási szerv"-ként definiálta. A mi szempontunkból itt a központi kérdés az önkormányzati jelleg visszahozatala a tanácsrendszer keretei közé. Az önkormányzat a tanácsrendszer viszonyai között nem a korábbi fogalmi körében érvényesült elsősorban, hanem szúkített, speciális jelentést hordozott. 


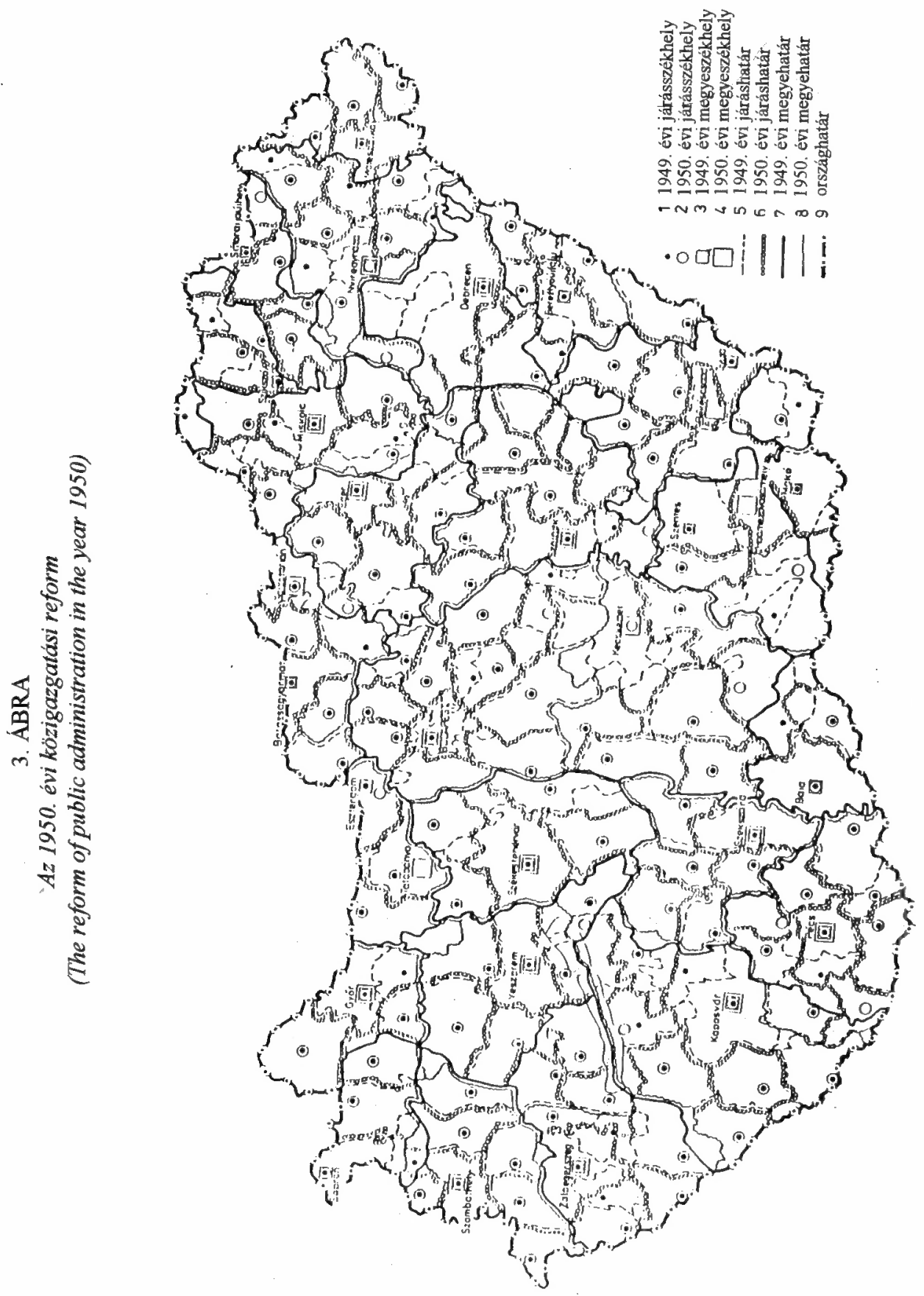


A tanácstörvény megszüntette a járási tanácsszintet, de a járás közigazgatási területegység maradt. A városok körül megindult, majd fokozatosan bövült a városkörnyékek szervezése. Ebben a konstrukcióban nem jött létre alá-fölérendeltségi viszony a testületek között. Sok, majd növekvő számú város körül párhuzamosan élt a szükebb városkörnyéki és a tágabb járási felosztás, mig a két felosztás versenye a városkörnyéki beosztás általánossá tételével ért véget 1984-ben.

\section{7) Rendszerváltás közigazgatási területi reform nélkül (1989-1990)}

A rendszerváltás elökészítése, az államszocialista rendszer válsága időszakában megjelenö régi és új politikai erök, mozgalmak, pártok programjaikban - eltérö célokkal és tartalmakkal - megfogalmazták a közigazgatási struktúra, benne a megye átalakítására vonatkızó elképzeléseiket. Ezek az elképzelések egy lényegi szempontban szinte teljesen megegyeztek: a korábbi tanácsrendszert szinte kivétel nélkül elutasitották, hitet tettek az önkormányzati közigazgatás megteremtése mellett.

A megye körül valósággal összecsaptak a politikai törekvések, ütköztek a hatalmi célok, megjelentek a különbözö jellegü és tartalmú indulatok is. Ezek a viták részben azt tükrözték, hogy mintegy a "megyének kellett elvinni a balhét" az államszocialista közigazgatás minden hibájáért, bünéért, hiszen minden esetlegesen hatalomra kerülö pártnak szüksége van központi és helyi közigazgatásra.

A városkörnyéki igazgatás megszünt, mert eredetileg is csak átmeneti jelleggel jött létre, $s$ általános jelleggel nem illeszkedett az önkormányzatiság új eszményébe. A társulások lehetöségeinek biztosításával akár az új feltételek között is fenntarthatóak voltak, de a települések elsősorban önállóságuk megélését tekintették elsődleges értéknek.

Az alkotmány IX. fejezete a helyi önkormányzatokról szólva egyformán önkormányzati jogokkal ruházta fel a községek, a városok, a föváros és kerületei, valamint a megyék választópolgárainak közösségeit, s megfogalmazta, hogy a helyi önkormányzatok alapjogai egyenlőek, de az önkormányzatok kötelességei eltérỏek lehetnek.

Az önkormányzati törvény előkészítése, kétharmados jellegénél fogva elfogadása, benne különösen a megye és a köztársasági megbizotti intézmény sokfaktorú és többször változó kompromisszum eredménye, melyben összekeveredtek a politikai célok, számitások, továbbá a közigazgatás érdekei. A megye önkormányzati közigazgatási jellegének csökkenése mellett megfigyelhetö, hogy felértékelödött a megye, mint területi keret. A változó és továbbépülö állami dekoncentrált szervrendszer elsődlegesen a megyékre épült rá. A köztársasági megbizotti intézmény és régiói többmegyés területi konfiguráció mellett jöttek létre - igaz, hogy meglehetősen vitatható területi egységeket képezve.

\section{III. Összegzés}

A magyar közigazgatás történeti térbeli fejlödése sok tekintetben folyamatos, de egyes vonatkozásokban többször megszakított, s ellentmondásokkal terhelt. A megye és a megyerendszer történeti képződmény. Változó, fejlődó, átalakuló organizmus mind hatásköre, szervezete, mind pedig területi struktúrája tekintetében. "Hatalma csúcspontját" a megye a XIX. század első felében érte el, a törvényhozás része, az igazságszolgáltatás 
területi letéteményese, általános közigazgatási hatóság, a végrehajtó hatalom legfontosabb területi szerve, saját területén szinte "élet és halál" ura.

A magyar történelem sajátosságai miatt a megye nemzeti intézménnyé vált az "idegen" központi törekvésekkel szemben, $\mathrm{s}$ a magyar társadalom vezetö elitje nemcsak saját rétegérdekei képviseletére tette képessé, alkalmassá, de nemzeti, alkotmány- és törvényvédő jelleggel is felruházta.

A modern magyar államiság és közigazgatás megteremtésekor az 1870-es években a már "nemzeti központi kormányzat" - melynek meghatározó képviselöit a megye és a megyegyúlések nevelték politikussá - a reálszférában túllép a megye történeti szerepén, bár megfogalmazásaiban a történeti hagyományokra hivatkozik. A parlamenti rendszernek megfelelően szabályozzák és korlátozzák a megyék hatáskörét, mozgáslehetőségeit.

A mindenkori hatalmi, politikai céloknak megfelelően korlátozták a megyei önkormányzatok hatáskörét a dualizmus és a két világháború közötti időszakban. A közigazgatás államosítása szinte feltartóztathatatlanul haladt elöre. $A$ "szocialista megye" bizonyos tekintetben megfogalmazható úgy is, mint a korábban elindult államositási törekvések végletes, ideológiailag meghatározott, deformált túlhajtása.

$\mathrm{Az}$ új önkormányzati megye "a két választás" terméke bizonyos mértékig. A többpártrendszer keretei között számolni kell a parlamenti többségnek és a kisebbségnek is azzal, hogy a helyi önkormányzatok "pártszínezete" nem mechanikus lenyomata a parlamenti erỏviszonyoknak. A rendszerváltás során a közigazgatás területén a funkcionális reform megtörtént, de a hatalomba jutott erőknek nem volt pillanatnyi érdeke a radikális területi reform, így az, mint már annyiszor, ismét elmaradt.

\section{Irodalom}

Ballagi K.-Király P. (1878) A Magyar Birodalom leirása, különös tekintettel az 1876. XXXIII. törvénycikkre. Budapest, Athenaeum.

Baráth T. (1943) Az országépités filozófiája a Kárpát-medencében. Kolozsvár. A szerző kiadása.

Beér J. (1962) A helyi tanácsok kialakulása és fejlődése Magyarországon (1945-1960). Budapest, Közgazdasági és Jogi Könyvkiadó.

Beér J.-Csizmadia A. (1966) Történelmünk a jogalkotós tükrében. (Sarkalatos honi törvényeinkböl, 1001-1949). Budapest, Gondolat Kiadó.

Bibó I: (1975) Közigazgatási területrendezés és az 1971. évi településhálózat-fejlesztési koncepció. Budapest, MTA Igazgatástudományi Bizottsága.

Cholnoky J. (1945) Vármegyéink földrajzi kialakulása. Földrajzi Zsebkönyv. Budapest, 313. o.

Csánky D. (1890-1913) Magyarország történeti földrajza a Hunyadiak korában. Budapest, I-III. kötet.

Csizmadia A. (1976) A magyar közigazgatás fejlódése a XVIII. századtól a tanácsrendszer létrejöttéig. Budapest, Akadémiai Kiadó.

Csizmadia A. (1979) Bürokrácia és közigazgatási reformok Magyarhonban. Budapest, Gondolat Kiadó.

Edelényi-Szabó D. (1928) Magyarország közjogi alkatrészeinek és törvényhatóságainak területváltozásai. Magyar Statisztikai Szemle, 6. 648-714. o.

Ember Gy. (1946) Az újkori magyar közigazgatós története Mohácstól a török kiüzéséig. Budapest, Magyar Országos Levéltár. 
Eötvös J. (1902) A XIX. század uralkodó eszméinek befolyása az álladalomra. Budapest, Révai, I-III. kötet.

Ereky I. (1910) A magyar helyhatósági önkormányzat. A vármegyék. 1. kötet. Budapest, II. kiadás.

Ereky I. (1942) A modern magyar közigazgatás kialakulása. Pécs, Pannónia Könyvtár.

Eszláry K. (1947) A közigazgatás területi reformjai. Városi Szemle, 1-2. 93-115. o.

Ferdinándy G. (1902) Magyarország közjoga. (Alkotmányjog.) Budapest, Politzer Zsigmond és Fia.

Fényes E. (1847) Magyarország leirása. Pest, Beimel.

Fényes E. (1857) Ausztriai Birodalom statistikája és földrajzi leírása. Pest, Heckenast Gusztáv.

Gyalay M. (1989) Magyar igazgatástörténeti helységnévlexikon. Budapest, TIT Nyomda.

Györffy Gy. (1963) Az Árpád-kori Magyarország történeti földrajza. I. kötet. Budapest, Akac'śmiai Kiadó.

Györffy Gy. (1977) István király és mũve. Budapest, Gondolat Kiadó.

Hajdú Z. (1991) Rendszerváltás, berendezkedés, területiség. (Közigazgatási területi reformtörekvések Magyarországon 1949-1956 között.) Magyar Közigazgatás, 4. 323329. 0.

Hajdú Z. (1993a) A magyar megyerendszer történeti, területi fejlődésének sajátosságai I. Comitatus, 1. 56-62. o.

Hajdú Z. (1993b) A magyar megyerendszer történeti, területi fejlödésének sajátosságai II. Comitatus, 2. 47-56. o.

Hantos Gy. (1931) A magyar közigazgatás területi alapjai. Budapest, Athenaeum.

Hencz A. (1973) Területrendezési törekvések Magyarországon. Budapest, Közgazdasági és Jogi Könyvkiadó.

Holub J. (1938) A királyi vármegyék eredete. In: Emlékkönyv Szent István király halálának 900. évfordulójára. Budapest, II. kötet. 71-106. o.

Horváth M. T. (1989) A tanácsrendszer alakulása és a kommunista párt területi hatalompolitikája (1948-1988). Budapest, Államigazgatási Szervezési Intézet.

Katona Z.-Szamel L. (1949) A megyék új határai. Állam és Közigazgatás, 5. 480-489. o.

Kolozsváry V.-Szamel L. (1950) A járások területének rendezése. Állam és Közigazgatás, 6-7. 45I-465. o.

Kristó Gy. (1988) A vármegyék kialakulása Magyarországon. Budapest, Magvető Könyvkiadó.

Kovács T. (szerk.) (1976) A tanácsrendszer negyedszázada. (Tanulmányok.) Budapest.

Magyary Z. (1942) Magyar közigazgatás. Budapest, Kir. Magy. Egyetemi Nyomda.

Molnár K. (1929) Magyar közjog. Pécs, 3, kiadás.

Némethy A. (1958) Magyarországi törvényhatóságok közigazgatási beosztásának változásai 1526 után. Történeti Statisztikai Közlemények, 3-4. 107-120. o.

Szamel K. (1981) A megyerendszer története Magyarországon. Budapest, Államigazgatási Szervezési Intézet.

Tomcsányi M. (1942) Magyarország közjoga. Budapest, Kir. Magy. Egyetemi Nyomda. 4. kiadás. 


\title{
CHANGES IN THE ADMINISTRATIVE SPATIAL DIVISION IN HUNGARY
}

\author{
ZOLTÁN HAJDÚ
}

While giving a brief introduction and analysis of the spatial history of Hungarian public administration, the author focuses on the following tendencies:

- in the historical-spatial development of the Hungarian public administration, continuity and interruption were present simultaneously, to a large extent in connection with the turning points of the history of the state.

- The most particular and most important regional unit of the Hungarian public administration was the county that itself changed several times with respect to both its function and spatial appearance.

- With the "foreign ownership" of the central power after 1526, the county developed into a special national-political institution and became the stage of national opposition.

- The historical county and county system reached the top of their power by the mid19th century: Participant of law making, the regional representative of jurisdiction, general authority of public administration, the most important regional organ of the executive power.

- The civil transformation weakened the feudal type power unit of the counties, with the separation of the branches of power, the former importance of the county governments declined, the state administration pushed county governments out of more and more significant fields.

- In the period of the civil transformation, a significant correction of the regional division of the counties took place, but carefully considering the historically formed county borders.

- The changes of the state border following World War I basically rearranged the regional order of inner public administration. The territorial and population imbalances among the counties were stronger than ever.

- Between the two world wars the nationalisation process of the public administration accelerated.

- Before and during World War II the administrative space of the counties pulsed according to the changes of the state border.

- The state socialist system, built between 1945 and 1950, carried out fundamental changes in the functions and operation of public administration, at the same time it only applied corrections in the regional structure.

- In the second half of the state socialist era some elements of self governments gradually appeared again in the Hungarian public administration, in a sense public administration approached the historical traditions of Hungary.

- The systemic change of self government public administration in 1990 brought a functional reform but not a real regional one. 
The reform of 1990 appreciated the role of the self governments of the settlements for the first time in the history of the Hungarian public administration, and it partly led to the fact that the regional governments were depreciated as never before in the administrative history of Hungary.

- The county governments had never been as weak and deprived of functions in the history of the Hungarian public administration as after 1990.

The Hungarian public administration and regional system is facing new challenges and bad needs for reforms. 